\title{
Women at Crossroads: Reconfiguring the Gender Roles in Select Indian Genre Fiction
}

\author{
Puja Chakraborty ${ }^{1}$ \& Krishanu Adhikari ${ }^{2}$ \\ ${ }^{1}$ Faculty member, Dept. of English, Malda Women's College \\ Email:puja6o14@gmail.com \\ ${ }^{2}$ Assistant Professor, Dept. of English, Kandra Radhakanta Kundu Mahavidyalaya. \\ PhD Scholar, Dept. of English, University of Hyderabad \\ Email: krishanu26489@gmail.com
}

\begin{abstract}
The inherent discursivity, entailing the composite category of 'The third world women' hinges on many contentious contours of female subjectivity, its genealogical and teleological subservience and submission to patriarchy, and the subsequent re-assertion of their identities and different female roles within the given rubric of patriarchal capitalist social order of the former colonies through strategic subversion, vis-à-vis negotiation of certain patriarchal ideals.The select novels, i.e. Anuradha Marwah Roy's The Higher Education of Geetika Mehendiratta (1993) and Advaita Kala's Almost Single (2007); from the discursive category of Indian genre fiction narrate two intersecting stories of two middle class Indian women, who have migrated to Delhi in pursuit of empowerment and to transcend the circumscribed trajectories of parochialism and stereotypical tropes of patriarchal order. Drawing inferences from these two texts, the present paper would like to look into the ethical question of women's empowerment in India, so as to 'problematize' the much appropriated subversion of gender roles, through a 'palimpsestic' assertion of female subjectivity, as evidenced in the seemingly divergent experiences of the two protagonists, within the unstable contexts of a postcolonial nation. Having engaged with the contested notion 'female consciousness', the paper further seeks to examine the veracity of such changes in the lived experiences of the women within the ever-shifting paradigms of 'post-national' and 'post-globalization' Indian milieu, while being placed against the multifaceted impediments, faced by them to bridge the two extremes; personal and professional affairs. Last but not least, the paper would also seek to shed some light on the equivocality, bordering the genealogical and generic classification(s) of the 'genre fiction', often under the charade of 'literary aesthetics' and critical/wide reception of these literary narratives.
\end{abstract}

Keywords: Third-World Feminism, Neoliberalism, Women empowerment, Indian middle class women, Indian genre fiction.

\section{Introduction}

The varying degrees of the concept of 'women empowerment' have engaged generations of scholars across the globe. One of the churning dialogues, crisscrossing the global feminist scholarship, roughly since the middle of the twentieth century is the underlying tension between the first world feminism and its oriental counterparts (postcolonial and third world feminisms), and the immanent differential and overlapping markers between them, depending upon the geopolitical, social and cultural contexts of their enquiry. The prevalent tensions within the intersectional approaches of global feminist criticisms, further, lead towards the much

(C) AesthetixMS 2020. This Open Access article is published under a Creative Commons Attribution Non-Commercial 4.0 International License (http://creativecommons.org/licenses/by-nc/4.0/), which permits non-commercial re-use, distribution, and reproduction in any medium, provided the original work is properly cited. For citation use the DOI. For commercial re-use, please contact editor@rupkatha.com. 
contemporary debates, grounded on the performative assumptions, adhering to the complex network of identity politics. The theory 'political' in/of identity formation, as well as an assertion, divulges the chauvinist elements in defining the female subjectivity as a subservient cultural construct. The methodology of resisting such regressive cultural labelling espouses to “disarticulate 'woman' from 'culture', deconstruct woman as symbol, reconstruct women as human beings and problematize women's rights as human rights” (Moghadam, 1993, p. 22). As the definition of 'the third world', by the postcolonial thinkers departs from the imperial praxes of homogenized 'othering' of the East by the Western "orientalist" discourses, the persistent call for an "intellectual decolonization" (Nigam, 2019) hinges on the assumptions of resuscitation of discursive traces of indigeneity(s), within the volatile and hegemonic political order of the postcolonies, which encourages heterogeneous expressions, through a collective adherence to normative social roles. Thus, within these complicit tropes of reified gender/power relations, the re-assertion of 'the Female' identity, through a gradual and incremental re-positioning and defiance of stipulated gender roles entails a persistent critique of heteronormativity as the only adaptive model, and an active resistance to the 'mainstreaming' of gendered narratives. Following Spivakian proposition of unlearning; through 'problematization' of the first world feminist theories, and a re-evaluation of ethnographic, cultural and functional 'differences' in the experiences of the women from the South-Asian countries, it could be plausibly argued, that the third world feminist scholarship ought to replace the commodity centered, patriarchal approach of "predictive usefulness" with a more gender-neutral, "mental-metric view" of individual potential, i.e. "what actual capabilities a person has" (Kynch and Sen, 1983, pp 363-36).

India as an exemplary third world nation, has substantially contributed to the existing criticism on 'developing' and 'underdeveloped' countries. The ontological, vis a vis teleological contradictions, characteristic of 'the third world women', and also of the 'third world', apart from these sociological studies, find ample resonance in the literary imagination(s) of the third world writers(located in/out[side] the geo-political boundaries). The present study aims to critically interrogate the literary ramifications of these churning questions, permeating the various social roles, played by the Indian middle class women, through a comparative reading of the select Indian genre fiction, i.e. Anuradha Marwah Roy's The Higher Education of Geetika Mehendiratta (1993) and Advaita Kala's Almost Single (2007). Despite having temporal/spatial/cultural contradistinctions, as evidenced in the lived experiences of the protagonists, a 'symptomatic' reading of these two texts would rather divulge some heretical questions, concerning the contested notion of 'women empowerment', located in New India, within the span of some twenty years; from the 1980 os to early post-millennial era. Responding to the underlying tensions in mapping the empowered status of Indian women, this paper further strives to understand how these two fictional narratives discursively engage with such challenges, through a systematic departure from embedded cultural prejudices and Daedalian gender stereotypes. Chronicling the transition in the 'performative' gestures/actions of Indian women also validates the drive to situate the evolution in the third world feminist discourses, within the shifting paradigms of the 'post-national' era, and to decipher how/why the female characters of the novels effectively endorse to and distance from much envisaged social reforms.

\section{Fragmented developments in the upward social mobility for women}

Chandra Talpade Mohanty's essay, "Under Western Eyes: Feminist and Colonial Discourses" (1988), which in a way marks the beginning of the feminist studies on the broader category of the third world women, works through certain incisive pointers to decipher the 'difference' and 
disjunction between the multifocal experiences of the women of color and their western counterparts. The works of feminist scholars such as Esther Chow, Catherine Berheide (1994), and Lourdes Beneria (1979, 1995), delve into the diverse range of socio-cultural and geo-political factors in the third world countries, responsible for the 'difference'(s) in patriarchal interpellation of women's subjectivity and its feminist counter expressions/discourses. While Beneria's criticism of patriarchy is more discursively and locally rooted in her firm belief on women's collective resistance to patriarchal domination, followed by the active re-assertion of female subjectivities through their claims of equality in terms of the financial, performative and other socio-cultural rights of women, Chow and Berheide further situate the demographic distinctions in the patriarchal attitude of the third world within the rubric of age, class, race, as well as geo-political 'difference'(s). The metaphor of 'difference', interfacing the feminisms of the first and the third world is further examined by Mohanty in the sequel; “Under Western Eyes” Revisited" (2003). The essay investigates the fragmented developments in the upward social mobility for women from the emergent nations with the changing economic conditions, due to globalization, thereby documenting an epistemological shift from an earlier persistence of ethnographic 'difference'(s), towards bridging the gap between 'difference' and 'commonality' in the third world and crosscultural feminist discourses. She proposes:

...(I)n knowing differences and particularities, we can better see the connections and commonalities, because no border or boundary is ever complete or rigidly determining. The challenge is to see how differences allow us to explain the connections and border crossings better and more accurately, how specifying difference allows us to theorize universal concerns more fully (Mohanty, p. 505).

This further unfolds the urgency of demystification, re-examination and theorization of newer forms of economic, racial and gender inequalities, within the deceptively homologous tropes of neoliberal economy and the national contexts of right-wing fundamentalism with their masculinist and racist narratives. This gradually indicates a repositioning in the third world feminist scholarship towards a more sustained 'anti-global' political critique of patriarchal and racist relations and structures.

A genealogical study of Indian Genre fiction/Pulp fiction traces back to a larger historical backdrop of their evolution in vernacular mediums. Tabish Khair, in the purview of two distinctive fictional subcategories-'Indian Fantasy Fiction' and 'Indian Romance Fiction', situates their origins in the marginal cluster of 'Bhasha-languages', and also brings in the wide public reception of such popular narratives within their respective regional trajectories (Khair, 20o8, p.6o, also see Bodhisattva Chattopadhyay, et al., 2018). In a similar vein, many of the exemplary fictional subgenres from this discursive category of 'Indian Genre Fiction' such as Indian Campus Fiction and Indian Chick-Lit, have much profound historical heritages both in English and other native languages. However, the proliferation of a diverse range of Indian Genre fiction in English, especially after the 1990s, indicates the shaping of a homomorphous urban culture in New India, with large-scale neo-liberal economic expansion and rise of the new middle class. This image of a changing nation is geared up by what might be termed as a 'post-millennial Indian moment' (Varughese, 2017), resulting in the opening of a liberal, domestic market for enhanced fiscal and cultural activities, thereby laying the foundation for a 'globalised' India. Dawson Varughese remarks: "It was Manmohan Singh, in his role as finance minister, who took the Indian economy forward from the 1990 s into the 2000 s prior to him becoming prime minister in 2004" (2017, p. 2). The debate over 'Globalization', as a 'boon' or 'bane' for the developing nations further evinces 
larger questions on the cultural homogenization/heterogenization, and the duality in the third world's position (self-reflexivity and compliance) with the neo-liberal market economy.

\section{Functional duality and the 'political unconscious'}

Following Jameson's analyses of the bi-directional, paradoxical response of the third world to the postmodern late-capitalist cultural praxes, it could be tenably argued that this functional duality effectuates the shaping of a distinct 'political unconscious', through thoroughgoing experimentations with emergent fictional genres and much contemporary social challenges of 'globalised' India. The 'palimpsestic' growth of Indian genre fiction in English discursively brings in several issues, pertaining to female empowerment in India; its accomplishments and ambivalences. Indian Campus novels in English, written by women writers, such as Rita Joshi's The Awakening (1992), Srividya Natarajan's No Onions Nor Garlic (2006), and Soma Das' Sumthing of a Mocktale (2007) conspicuously throw light on the crucial question of the role of women's education in India in safeguarding/reinforcing the gender equality and elevating the social status of women, both in family and in larger structure. The Awakening(1992) delineates a realistic portrayal of women's education in a provincial Indian college during late $1980 \mathrm{os}$, so as to problematize the 'discontinuities' in the practical manifestations of reformative measures, espousing female literacy. While Natarajan, and Das, in their respective novels explore the contradictions/complicities, entailing the different female positions at the metropolitan Indian universities in the $21^{\text {st }}$ century, No Onions Nor Garlic (2006) also traverses through the oft-mooted question of 'subaltern women' in Indian academia. On the other hand, Indian Chick Lit, a relatively new fictional genre in Indian English literature engages with the lived experiences of middle class urban women in the post-millennial Indian milieu. Despite having disparagingly labelled as 'fluffy', "formulaic vapid prose" (Ponzanesi, 2014, p. 157), these works of fiction very often provide a broader, 'heterotopic' perspective in re-imagining the"(trans)national racialized feminine subject embedded within neoliberalism, heteronormativity and racism" (Butler, and Desai, 2008, p.2). Amulya Malladi's The Mango Season(2003), and Kavita Daswani's The Village Bride of Beverly Hills (2005) present such neoliberal and (trans)national/cultural female subjects within the ever-dynamic contexts of a postcolonial nation, and also tend to analyze the perpetual ambivalence in patriarchy in acknowledging the individual choices/decisions of women in the purview of their marriage, evident enough in the post-liberal urban spaces of new India, often carrying the "burden of culture"(Ashcroft2011). While Anuja Chauhan's Battle of Bittora (2010) draws a feminist fictional historiography of such transitions and envisaged changes in their life choices, through the evolution of its female protagonist, Rekha Waheed's A-Z Guide to Arranged Marriage (2005) hovers around the idea of marriage in Muslim community and the problematics of identity formation of Muslim women.

The Higher Education of Geetika Mehendiratta (1993), which is written in the form of 'bildungsroman', and set in a post-independent India between the late 1970 and 8os, dialectically engages with the multilateral scholarly debates on the concept of female education in India, as an indispensable tool for women empowerment. The protagonist Geetika, hailing from a small town in Rajasthan embodies different perspectives on women's liberation through her formal education. Anuradha Marwah Roy's imperative questions/propositions on the crumbling collective consciousness with respect to the dissemination vis a vis reception of women's education in India are articulated through the prevalent antinomies, discernible in the responses of Geetika's family and her friend Vini's. Vini's undiscerning acceptance of the regressive presuppositions and stereotypes of the patriarchal order, is adequately echoed in her attempt to 
persuade Geetika to compromise with her individual aspirations and abide by the norms of heteronormative social order.

What is so unreasonable about it, Geetika?...you will have to meet his parents, ultimately. You said you were going to marry him...Why you are twenty already, aren't you? You can't wait till you are thirty...Come on Geeti, go and charm them. They will be so glad that their son has chosen such a fair complexioned bahu and one so intelligent... (Marwah, 1993, p. 15).

This symbolically re-affirms the essential patriarchal disposition of restricting/appropriating the female gender roles within the prescribed trajectories of domesticity, through a deliberate cooption of female subjectivity, as argued by Karuna Chanana in her essay: "The Dialectics of Tradition and Modernity and Women's Education in India" (1990). "Notwithstanding the accent on women's education, the gender role expectation of and about women continues to be that of a home maker. This role definition has been internalized by even those women who have had access to modern education and to career opportunities" (p. 76).

Geetika's much precarious and tedious academic journey which began in an imaginary provincial town called 'Desertvadi' and culminated in her acquiring a lectureship in a govt. degree college in Delhi, is emblematic of a radical distancing from the parochial patriarchal morals of post-national India. Geetika's school education clearly reflects upon the reformative measures taken after the independence to advocate female literacy, such as free primary education and several fellowships for women, owing much to the feminist and liberal clairvoyance of the social reformers. The committees such as National Committee on Women's Education (1958-59), Committee on Differentiation of Curricula for Boys and Girls (1964), and Committee on the Status of Women in India (1971), in their reports expressed great concern over the staggered progress of women's education in the initial decades after independence and pressed on the urgency of uniformity in promotion of female education, by opening up educational institutions for women in peripheral areas, and enlightening people about the domestic and larger socio-economic interests of educating the girl child. Their recommendations urging the government to consider the challenge of women's education "as a major and special problem of education for a good many years to come" (1958-59, p. 5) and "to close the existing gap between the education of men and women in as short a time as possible" (p. 6) witnessed a considerable rise in enrollment of female students, with an increasing number of girls' educational institutions and recruitment of female teachers. But despite these liberal endeavors to revolutionize the female education in India, the stumbling blocks of patriarchal tradition and much naturalized female identity, essentially tied up with marriage and her role in the family are discursively addressed by Anuradha Marwah, through Geetika's resentment and questioning of her friend Mahima Kumari's marriage, even before she turned eighteen. This in turn unmasks the liminalities, permeating the perennial challenges of women's education and its lopsided development, as evidenced in "different states, different regions in a state, rural and urban areas and socio-economic strata” (Kamat, 1976, p. 8).

With the unfolding of the narrative, the nuanced presence of patriarchal and capitalist discourses, coupled with a conniving political strategy of 'appropriation' of female roles become much discernable, irrespective of temporal and spatial differences. The novelist has deftly demonstrated the socio-cultural tensions and prejudices, present in average middle-class Indian families, concerning the raison d'etre of female education. After the completion of her college education, Geetika's decision of joining a university in a fictitious city of Lutyenabad, which is tenably analogous to JNU, Delhi; to pursue higher studies during the early 1980s; was much resented by some of her family members, her boyfriend and even his family members. Andy's 
insistence on their marriage and emphasis on Geetika's primary role as 'wife' and 'mother', also visible in Ratish and his family's expectations from her later on, dispensing with her academic aspirations, unveil the ever-widening rupture between theoretical propositions and their realistic manifestations, while problematizing the atavistic demeanor of New Indian men. Thus, despite the visionary ideals of strengthening the female social roles and upliftment of women's social statusin post-independence India, the underlying contradictions in the dominant patriarchal attitude of the nation, tend to delimit/appropriate the socio-cultural virtue of women's education within the restricted boundaries of the family. Drawing references from the historical evidence and contemporary records, VinaMazumdar rightly problematizes this over-powering patriarchal trend in the introductory chapter of her edited volume: Education, Equality and Development: Persistent Paradoxes in Indian Women's History(2012). She questions: "Was the main objective strengthening women's primary social role-as rearers of the young generation, or to bridge the mental gap vis a vis their husbands? Or was it to assist their men's social advance?" (Mazumdar, p. $\mathrm{xx}$ ).

Thus questioning the stereotypical expectations of patriarchy and socio-political matrices of a supposedly liberal India and transcending the complicit boundaries during the 1980 os were the radical challenges, encountered by a third world middle-class woman in her early 20 .The road, leading to a feminist assertion of her individuality, through an unrelenting subversion of fixed gender roles, is fettered with multiple conflicts, ranging from a persistent 'lack' in her personal life to a ceaseless battle for her 'existence' and assertion of her identity in a power-ridden Indian society. Geetika's decision of opting for a career in academics, breaking off the engagement with Ratish even after the news of her pregnancy, and her final decision of being a single mother to her child exemplify a paradigm shift from the over-powering chauvinist ethos. The positioning of single motherhood as a taboo/stigma in the society is often identified as an act of adultery and even prostitution. The public defamation of her as a prostitute, by her own students, apart from reiterating the entrenched patriarchal prejudices, and the moral degradation of Indian men, also subtly satirizes the lack of a collective non-gendered consciousness, amongst them. The following reaction of the principal, which is characterized by a hostile intention of professional harassment, instead of empathy, is further evocative of the dominant patriarchal ideology of segregating and controlling women's individuality through vindictive coercive approaches. Thus Geetika's resistance, through retaining her individualist choices is symptomatic of a projection of an identity which is not always self-evident, within a definitive structural position, but is created and emerges through a process of a prolonged collective struggle(Berger 1992, Ray and Korteweg 1999).

The multifaceted projection of her 'emancipated' self through her life-choices, bears an index of a radical, yet mediatory positioning of female representation in the ever-shifting Indian contexts. This constant oscillation between these two extremes reflects in her self-revelation:

"Mummy...I lost Ratish...I became too much your daughter...I became Geetika who earned her living, I became Geetika who was trying to write. I wrote incessantly, resolutely turning Ratish away in the evenings. I was trying to work out a system in which toexist" (Marwah, 1993, p. 189).

Her creative writings create a 'heterotopic' space for a palimpsestic utterance of her own struggle with normativity and of the devious presence of loneliness, schizophrenia and emotional vulnerability, confronting the lived experiences of 'empowered' Indian women.The underlying existential crisis, as a perpetual signifier of her self-discovery, through denial and transcendence of conventional boundaries, exemplifies an average middle-class third world woman's ceaseless 
intrapersonal and interpersonal struggle with the dominant phallocentric ideologies in her claim for equal gender rights.

\section{Market society and postmodern individualism}

In the neoliberal-capitalist 'market society', the discourse of gender representation is more than a challenging one. The fragmented salience of 'postmodern individualism' within the domain of the new wave feminist discourses constitutes an explanatory frame for this 'progressive', an emblematic of neoliberal ideologies, yet complex matrix of self-efficacious and self-formulated definition of identity. One of the strengths of this 'progressivism' lies in its refusal of any 'singularliberal-humanist subjectivity' (Reed, 1997, p. 124). Judith Butler (1990) has explained that the concept of gender as essentially "a performative repetition of acts" that can be associated with any male or female body. She further rejects the singularity of the biological determinant to assign the 'gender role' and stresses more on the act of "behaviour" which through revisions, reassertions and reformulations over the time, can achieve a position of identity. Thus, the idea of 'femininity' is inadvertently characterized by diversity, fragmentation and a series of contestation, thereby, questioning its monolithic definition and the subsequent representations. The regime of representation has shifted from political rights (a second-wave phenomenon) to subjective choices (essentially based on those rights), hence, dialectically producing a palimpsestic effect of 'female identity'. Within this framework, Advita Kala's Almost Single (2007) attempts to delineate certain dimensions to assess the nature of this cosmopolitan identity of young, middle-class, working-women through the lens of postcolonial-feminism, contouring the neoliberal discourses.

The protagonist of Almost Single (2007), Aisha Bhatia, who migrates from Nashik to New Delhi, the metropolitan hub of corporate agencies for 'progressive' career options, is "on the wrong side of twenty-nine" (Kala, p. 4), i.e. still unmarried, adhering to the orthodox Indian culture. Aisha as a young successful working-woman (she works as the 'Guest Relations Manager' at the Grand Orchid Hotel) takes an active part in the grand culture of capitalism and consumerism, thus, becomes a signifier to 'an autonomous subject position'. She represents the prototype of the "new woman" as articulated by Rajeswari SunderRajan(1993), who asserts "She (Indian woman) is 'new' in the senses both of having evolved and arrived in response to the times, as well as being intrinsically 'modern' and 'liberated"'(p. 124). Aisha's social circle is loosely confined to Misha and Anushka, her childhood friends along with Nic and Ric, the gay couple with whom she drinks, shops and goes to parties. Her position as a 'liberated' woman aptly places her at the centre of conflict between tradition and modernity. For that, Aisha is under the constant pressure of finding her 'Mr. Right'. Her everyday flow of work and socialization is frequently interspersed with her mother's call who constantly persists her to obtain a 'perfect' groom which indicates an NRI or someone with close proximity to that, without which her social acceptability is disparaged; but when Aisha seems disinterested, Mrs Bhatia dishearteningly complains: "Everyone is getting married now. Chalo, it's all karma at the end of the day" (Kala, p. 12). The struggle to incorporate this conflict between the traditional norms of marriage, within a stipulated age and the modern cultural ideals of maintaining a position of choice, creates a complex juncture for particularly the young working-women for whom the limits to overcoming so are attributed with an undue psychic cost for individual failures as they oftentimes fail to bridge the unbending gap between the 'right' choice and unquestioned submission to normative structure (Budgeon, 2011, p. 286). In their article, Pamela Butler and Jigna Desai (2008) have convincingly argued:

As the postcolonial nation-state modulates the binary of traditional and modern, one of the most significant sites of contestation and negotiation is family, specially the joint 
Indian family that is framed as being able to withstand the onslaughts of modernity...(p. 16)

Therefore, marriage becomes a problematic site for contested ideas to contrast as well as discursively converge. On the same length the novel also underscores the liminalities of arranged marriage as a mode of celebrating endogamous marital practices through cultural affiliation. Aisha's cousin, LataDidi, confesses dishearteningly, "Now he drinks to get drunk. But what do I do? It's been over ten years now and I'm only a college graduate. Where can I go? Papa has also retied. Aisha, it's good you have waited. You have a job, a life, friends, an identity... you know something, you will never be lonely" (Kala, p. 266). The predicament of women in unsuccessful marriage, even after being approved by the families, is the locus of ideological struggle that third wave feminism exceptionally promotes. As argued by Shelley Budgeon (2011), the key concept of female emancipation is permeably tied to the shifting modalities of economic progression, advanced information technologies, demographic changes, and diverse modes of sexuality, among other drives. According to her:

Third-wave feminism represents one strategy for negotiating the contradictions that constitute a late modern female empowerment discourse. This discourse is underwritten by the assertion that women's access to an autonomous subject position increased significantly in the latter half of the twentieth century resulting in women's ability to define their own identities independent of their relations to others (p. 284).

She explains the trajectory of modern women, shedding the 'victim' self behind and achieving the position of 'power feminism'. Heywood and Drake (2004) expound this paradigm shift by examining the new levels of gender parity in educational as well as occupational attainments by which, they assume, women are more attuned with their generation rather than gender. Such circumstances, by and large, help to produce generative knowledge that can flexibly address the heterogeneous nature of the feminist agenda.

The novel revolves around the multiple threads of 'acceptability', both personal and societal, which is questioned, refused and negotiated by almost all the characters. Misha's groom-hunting lands her on the wrong side of the rope for multiple times, her 'living alone' status has brought numerous misjudgments from the co-inmates of her building as Mrs. Mukherjee, her neighbour "has a fixed notion of bhadralok and Misha just doesn't cut it" (Kala, p. 78), Anushka refuses to compromise her position in the marriage when she discovers her husband's infidelity, Aisha never plans to settle in with any random man just because she is nearing her thirties. In fact, her nonconformist nature impels her to question the very way society wants the women to represent themselves; as at times she has to drape her saree over jeans instead of the petticoat, disdaining the hotel protocol, she laments:

People always wonder why I have not met a nice man at work yet. It's because of the saree-I call it the male repellent. Yes, I know a lot of women look stunning in it. I am not one of those women... Its basic design flaw, sarees should come with a stitched-on petticoat (Kala, p. 183).

By playing these subversive roles, deploying the disruptive practices of normative society, as A. C. Licona (2005) proposes, the third-wave female subjects create self-assertive identities which evade the effects of 'phallogocentric' representational strategies. These spaces are exponentially fertile as they allow to formulate certain forms of hybridized female subjectivity. The conflict between traditional arranged marriage and the neo-liberal tropes of 'choice' plays an intriguing part in the life of young working-women. The institution of marriage has a 
preponderant power position in Indian cultural repository; that is why there is a constant brewing tension among Aisha and her friends. As a liberal woman, Aisha prefers to exercise her rights of 'choice' in the domain of marriage that can incorporate the elements of love and compatibility. Although she occasionally consults the Swamiji (a Hindu astrologer) to check for a suitable time for marital connection, at heart she knows that marriage is not a divine conspiracy, rather a thoroughly-charted calculative move. Even after being proposed by Karan with whom Aisha feels an emotional connection, she takes a step back and asserts:

"So we are together then? Together because we love each other's company? Not because we're bound to do the right thing or what's expected?"

“Meaning?" He asks, looking really confused.

"What I'm trying to say is that I'm okay being the oldest bride in India just as long as when I do get to be a bride it is the right man." (Kala, p. 281).

This is how the competing discourses of female agency, the politics of identity, and the moment of empowerment are addressed, if not completely achieved, in the contemporary trans-cultural social milieu. Through her assertive position, Aisha attempts to create a generative space that further indicates how the intersectional ideas of individuality and empowerment bridge with the micro-politics of the contemporary changing society of the New India.

Following Fredric Jameson's definition of the fictional narrative as a potential site, which symbolically engages with substantial, yet unconsciously felt socio-cultural tensions/predicaments (1981), it could be argued that the role of criticism lies in not only locating the discursive traces of 'the political unconscious' in the particular work, but also in examining/critiquing the text's 'dialectical' position, with respect to the prevalent problems. Anuradha Marwah Roy's The Higher Education of Geetika Mehendiratta(1993) and Advaita Kala's Almost Single (2007), as representative works of Indian genre fiction effectively bring in the sociocultural hindrances, faced by an average Indian middle class woman in reformulating the gender roles, set by the patriarchy, through reification of adverse psychological crisis/trauma, the protagonists and other female characters from the novels are subjected to. While Geetika's quest for an individual female identity in 1980s, coupled with her persistent loneliness, gradually give way to Aisha's much homogenized notion of a social acknowledgement in 'globalized' India, with its own claimsof feminist re-assertion and theconcomitant baggage of mental trauma, a 'dialectical' positioning of the underlying interstitial junctures in their subjective experiences, allows us to locate the fictional subjectivity within the larger connotations of transitional development of female empowerment in India. The narrativestructure of both the novels proves conducive enough to investigate the contradictions, and the partial accomplishment of female empowerment in post-independence India from a self-reflexive 'defamiliarized' point of view.A synchronic,vis a vis diachronic readingof the moments of variations/intersections in their pursuits, situates the two texts dialogically with the larger question of the shift in public consciousness, through an incremental advancement of learning among Indian women. WhereasGeetika'sdecisions in life were not much favored by many, and signify a radical subversion of patriarchal ideals, the estrangement in Aisha's life is comparatively lesser, which is symbolic of a gradual transfiguration in the collectivepatriarchal psyche of the urban areas, along with the progression in the consciousness of women.

\section{Conclusion}


The above discussion on the scope of re-imagining the Indian women through reparation, and reassertion of female selves, as manifest in the two select Indian genre fiction in English, in a way accentuates the call for an eclectic enquiry on how the controversies, surrounding the peripheral status of the genre fiction generate a dialogic spacefor a 'polyphonic' engagement with the multifaceted, yet marginalized socio-political and cultural issues, among which the formation of female agency and its diverse manifestations constitute a vital part. Historically the origin of 'genre fiction' could be traced back to the popular Victorian romances, fantasy tales, detective and science fiction of the late $19^{\text {th }}$ century. The clustering and a homogenized classification of some fictional works as 'genre fiction'/ 'pulp fiction'/ 'popular fiction' very often rest on the ambivalent and equivocal grounds of literary aesthetics. The rise in scholarly debates on the use of 'popular' in literature/culture is attributed to Italian Marxist philosopher Antonio Gramsci's (1929-35) definition of 'popular' culture and literature in an early twentieth century Italy, as a collective national resistance against the dominant bourgeois socialist culture. On a similar tone, though in a different context,Deleuze and Guattari in their essay, "What is a Minor Literature" (1983) essentially worked through three incisive pointers, in understanding a minor/political/resistant literature -i) 'the deterritorialization of language', ii) 'the connection of an individual to a political immediacy', and iii) 'the collective arrangement of utterance'. Within a post-structural fabric, they formulate the use of language as 'deterritorialized' i.e. free from any semiotic constraints, constantly in a state of 'becoming' which eventually frees literature from monolithic identity, and therefore opens up newer avenues for exploration. Adhering to this 'revolutionary' structure, Indian genre fiction with its inherent ambivalences as well as ambiguities congruously employs its marginalized status to encompass numerous strands of critical junctures. This article, in its attempt to critically situate the discursive markers of a feminist 'dasein', within the chameleonic fabric of a postcolonial nation, builds upon the textual representations of territorial conflicts between the problematics of identity formation in (post)national/globalized Indian contexts and the tradition of patriarchy. Thus, a wider social recognition of emancipatory life choices of Indian women, as evidenced in the above mentioned works of Indian genre fiction in English prepares the ground for further evaluation of broader issues such as-- female sexuality and its transgression, disjunctions in practical manifestations of women labor, and the culture of 'ageing', with the enmeshed patriarchal 'interpellation'. Such interventions hope to expedite the process of re-writing an alternate feminist version of Foucault's "history of the present", with a systematic resurgence in the global consciousness on the baneful consequences of the women's roles as gendered subjects.

\section{Bibliography}

Ashcroft, Bill. (2011). "Urbanism, Mobility, and Bombay: Reading the Postcolonial City". Journal of Postcolonial Writing, Vol. 47, no. 5. pp. 497-509.

Beneria, Lourdes. (1979). "Reproduction, Production, and the Sexual Division of Labour". Cambridge Journal of Economics, Vol. 3, no. 3. pp. 203-225. Retrieved from. https://www.jstor.org/stable/23596391.

Budgeon, Shelley (2011). "The Contradictions of Successful Femininity: Third-Wave Feminism, Postfeminism and'New' Femininities” in. Gill, Rosalinde, and Scharff, Christina, eds. New Femininities Postfeminism, Neoliberalism and Subjectivity (pp. 279-292). Basingstoke: Palgrave Macmillan.

Butler, Judith. (1990).Gender Trouble: Feminism and the Subversion of Identity. New York: Routledge. 
Butler, Pamela, and Desai, Jigna. (2008). "Manolos, Marriage, and Mantras: Criticism and Transnational Feminism.” Meridians: Feminism, Race, Transnationalism. Vol. 8, no. 2. pp. 1-31

Cawelti, John, G. "The Concept of Formula in the study of Popular Literature", in. Hinds, Harold, E. Jr, Motz, Marilyn, F, and Angela, M. S. Nelson, eds. (2006). Popular Culture Theory and Methodology: A Basic Introduction. London: The University of Wisconsin Press.

Chanana, Karuna. (1990). “The Dialectics of Tradition and Modernity and Women's Education in India”. Sociological Bulletin, Vol. 39, no. 1/2. pp. 75-90.

Chattopadhyay, Bodhisattva, et al. eds. (2018). Indian Genre Fiction: Pasts and Future Histories. Delhi: Routledge.

Chow, Esther, Ngan, and Berheide, Catherine White, eds. (1994). Women, the Family, and Policy: A Global Perspective. New York: SUNY Press.

Colas, Santiago. (1992). "The Third World in Jameson's Postmodernism or the Cultural Logic of Late Capitalism". Social Text. No. 31/32: [Third World and Postcolonial Issues]. pp. 258-270. Retrieved from. http://www.jstor.org/stable/466230.

Deleuze, Gilles, and Guattari, Felix. (1983). "What is a Minor Literature”. Mississippi Review, Vol. 11, no. 3. [Essays on Literary Criticism]. pp. 13-33.

During, Simon, ed. (2007). The Cultural Studies Reader. $3^{\text {rd }}$ ed. London: Routledge.

Edgar, Andrew and Sedgwick, Peter. (2004). Key Concepts in Cultural Theory. London: Routledge.

Edgerton, Susan et al, eds. (2005). Imagining the Academy: Higher Education and Popular Culture. New York: Routledge.

Gramsci, Antonio. (1992). Selections from the Prison Notebooks (Quintin Hoare and Geoffrey Nowell Smith, Trans.). New York: International Publishers.

Gutting, Gary, ed. (2007). The Cambridge Companion to Foucault. $2^{\text {nd }}$ ed. New York: CUP.

Heywood, L. and Drake, J. (2004). 'It's All about the Benjamins: Economic Determinants of Third Wave Feminism in the US', in. Gillis, S, et. al. eds. Third Wave Feminism. Basingstoke: Palgrave Macmillan.

Heywood, L. and Drake, J. eds. (1997).Third Wave Agenda: Being Feminist, Doing Feminism. Minneapolis: University of Minnesota Press.

Jameson, Fredric. (1981). The Political Unconscious: Narrative as a Socially Symbolic Act. London: Metheun.

Kala, Advita. (2007). Almost Single. New Delhi: Harper Collins Publishers India.

Kamat, A. R. (1976). “Women's Education and Social Change in India”. Social Scientist, Vol. 5. No. 1. pp. 3-27. Retrieved from. http://www.jstor.com/stable/351660o.

Kothari, D. S, et. al. (1966). Report of the Education Commission, 1964-66. New Delhi: National Council of Educational Research and Training.

Kynch, J, and Sen, Amartya. (1983). "Indian Women: Well-Being and Survival”. Cambridge Journal of Economics, Vol. 7, no. 3/4. pp. 363-380. Retrieved from. http://www.jstor.org/stable/23596593.

Licona, A. C. (2005) "(B)Orderlands' Rhetorics and Representations: The Transformative Potential of Feminist Third- Space Scholarship and Zines”, NWSA Journal Vol. 17, No. 2, pp. 104-29.

Mazumdar, Vina, ed. (2012). Education, Equality, and Development: Persistent Paradoxes in Indian Women's History. Delhi: Pearson.

Ministry of Education. (1960). Report of The National Committee on Women's Education: 1958-59. New Delhi: The Manager Government of India Press Ltd. 
Moghadam, Valentine, M, ed. (2018). Identity Politics and Women: Cultural Reasseertions and Feminisms in International Perspective. New York: Routledge.

Mohanty, Chandra, Talpade. (1988). "Under Western Eyes: Feminist Scholarship and Colonial Discourses". Feminist Review, No. 30, pp. 61-88. https://doi.org/10.1057/fr.1988.42.

...(2003). “Under Western Eyes” Revisited: Feminist Solidarity through Anticapitalist Struggles”. Signs, Volume 21, No. 2, pp. 499-535. Retrieved from. http://www.jstor.org/stable/10.1086/342914

Nigam, Aditya. (2019). "Decolonizing the University", in Bhattacharya, Debaditya, ed. The University Unthought (pp. 62-73). New Delhi: Routledge.

Ponzanesi, Sandra. (2014) “Postcolonial Chick Lit: Postfeminism or Consumerism?" in The Postcolonial Cultural Industry: Icons, Markets, Mythologies. (pp. 156-227) London: Palgrave Macmillan.

Rajan, Rajeswari, Sunder. (1993). "Real And Imagined Women: Politics and/of representation" in Real and Imagined Women: Gender, Culture and Postcolonialism. (pp. 123-139) London: Routledge.

Ray, R, and Korteweg, A. C. (1999). "Women's Movements in the Third World: Identity, Mobilization, and Autonomy”. Annual Review of Sociology, Vol. 25. pp. 47-71. Retrieved from. https://www.jstor.org/stable/223497.

Reed, J. (1997). “Roseanne: A “Killer Bitch" for Generation X”. in Heywood, L, and Drake, J, eds. Third Wave Agenda: Being Feminist, Doing Feminism. Minneapolis: University of Minnesota Press.

Roy, AnuradhaMarwah. (1993). The Higher Education of Geetika Mehendiratta. Hyderabad: Orient Longman.

Spivak, Gayatri, Chakraborty. (2013). “Can the Subaltern Speak?”, in Williams, Patrick, and Laura, Chrisman, eds. Colonial Discourse and Post-Colonial Theory (pp.66-111). Oxon, New York: Routledge.

Varughese, Dawson, E. ed. (2017). "Introducing the Post-Millennial Scene" in Genre Fiction of New India Post-Millennial Receptions of 'Weird' Narrative. New York: Routledge. 